\title{
Financial Inclusion And Income Inequality: Does Financial Structure Matter?
}

\author{
Inklusi Keuangan dan Ketimpangan Pendapatan: Apakah Struktur Keuangan Penting?
}

Indana Zulfa Sari ${ }^{1}$, Telisa Aulia Falianty ${ }^{2}$

Fakultas Ekonomi dan Bisnis, Universitas Indonesia

Jl. Margonda Raya, Pondok Cina, Depok 16424, Indonesia

Korespondensi: indanazulfasari@gmail.com

[diterima: Maret 2021- revisi: April 2021-diterbitkan daring: Juli 2021]

\begin{abstract}
ABSTRAK
Terdapat perdebatan mengenai dampak inklusi keuangan terhadap ketimpangan pendapatan. Dampak inklusi keuangan terhadap ketimpangan pendapatan kemungkinan besar bergantung pada banyak faktor. Penelitian ini bertujuan untuk menginvestigasi dampak inklusi keuangan terhadap ketimpangan pendapatan kondisional pada struktur keuangan. Penelitian ini menggunakan data 33 provinsi di Indonesia dari tahun 2010 hingga 2020. Metode analisis yang digunakan adalah static panel data model. Hasil penelitian ini menunjukkan bahwa inklusi keuangan dan struktur keuangan tidak berdampak signifikan terhadap ketimpangan pendapatan. Akan tetapi, untuk provinsi dengan nilai HDI kategori tinggi, inklusi keuangan dan struktur keuangan berdampak signifikan negatif terhadap ketimpangan pendapatan. Kebijakan mengenai inklusi keuangan untuk mengatasi masalah ketimpangan pendapatan perlu memperhatikan karakteristik setiap wilayah, khususnya kualitas sumber daya manusia.
\end{abstract}

Kata Kunci: inklusi keuangan, struktur keuangan, ketimpangan pendapatan

\begin{abstract}
There are current debates regarding the effect of financial inclusion on income inequality. The effect of financial inclusion on income inequality might be conditional to several other factors. This study aims to investigate the effect of financial inclusion on income inequality conditional to financial structure. This research used Indonesia's 33 provinces yearly data from 2010 to 2020 . Analysis method that was used in this study was static panel data model. The result showed that financial inclusion and financial structure does not significantly affect income inequality. However, for provinces with high HDI, financial inclusion and financial structure demonstrate significant and negative effect on income inequality. Policies on financial inclusion to solve the problem of income inequality needs to consider characteristic of each region, especially human resource quality.
\end{abstract}

Keywords: financial inclusion, financial structure, income inequality, panel data regression

JEL Classification: G20, I30 


\section{INTRODUCTION}

The problem of income inequality is one of major issues in global discussion regarding economic development. It means income differences between economic groups are getting further. Ray (1998) argues that the concern of inequality needs to be addressed because of philosophical and ethical reasons. Todaro \& Smith (2012) explained further that income inequality is a potential factor of inefficiency in economic and a trigger of many social problems such as rent-seeking, bribery, and cronyism due to an overly-high-power hold by the richest part of population in a country. Kuznets (1955) and Piketty (2014) states that income inequality is correlated by growth. Kuznets (1955) proposes inverse-U shape correlation while Piketty (2014) propose S-shape correlation. Other than growth, there are also several factors that determine the movement of income inequality, they are government spending, subsidies and transfers, resource endowment, political risk, unemployment, and inflation (Deyshappriya, 2017), financialization, trade union, and labor (Tridico, 2017).

Various attempts on reducing income inequality are being formulated and currently implemented in many regions. Most of the attempts include government programs that ensures inclusivity of many aspects, including education, health, and finance. Inclusivity of financial sector is considered an important aspect to reduce poverty and income inequality. Dhrifi (2013) argues that financial sector affects poverty reduction in both direct and indirect link. Direct link, includes access to saving, credit, insurance, etc.; allows the poor to benefit from those services to manage their asset, increase its productivity, and enhance their access to a better quality of education and health facility. Meanwhile, the indirect link involves the effect of financial sector to growth. The increase of growth allows poverty reduction to occur.

Financial institutions ensure a bridging of fund from a surplus unit to a deficit unit ${ }^{1}$. Financial institutions include banks, insurance companies, securities, leasing, venture capital, etc. A financial institution is deemed as efficient if it is implied and operated such that it meets the expectation of both parties. Moreover, an efficient and effective financial system fosters economic growth and reduces poverty (Erlando et al., 2020). World Bank (2019) defined financial inclusion itself as the creation of access to useful and affordable financial products and services for individuals and businesses. It includes transactions, payments, savings, credit, and insurance. Those products are expected to be delivered responsibly and sustainably.

Figure 1 demonstrated financial inclusion represented by financial inclusion index by Sarma (2015), income inequality represented by Gini ratio, and GDP of several countries in the world. The bar chart is sorted based on GDP. The right side of the chart demonstrated the higher value of GDP. Based on the figure, high income countries, represented by several countries such as Germany, United Kingdom, France, and Italy, demonstrated a fairly high score of financial inclusion and relatively low level of income inequality compared to middle- and low-income countries.

The problem of financial inclusion is likely to be a more prominent problem for middle- and low-income countries than for high-income countries. High-income country

\footnotetext{
${ }^{1}$ Surplus unit means individuals or parties that possess an amount of fund that is more than what they are willing to spend in a certain period of time, while the deficit unit means individuals or parties that have less than what they are willing to spend in a certain period of time.
} 
is associated with developed countries which already has well-established financial system and well financially literate people. Meanwhile, developing countries still has long way to go to develop a stable financial system, and increase financial literation as well as financial inclusion. The different nature of different country makes it important to observe the behaviour of financial inclusion and income inequality in different regions.

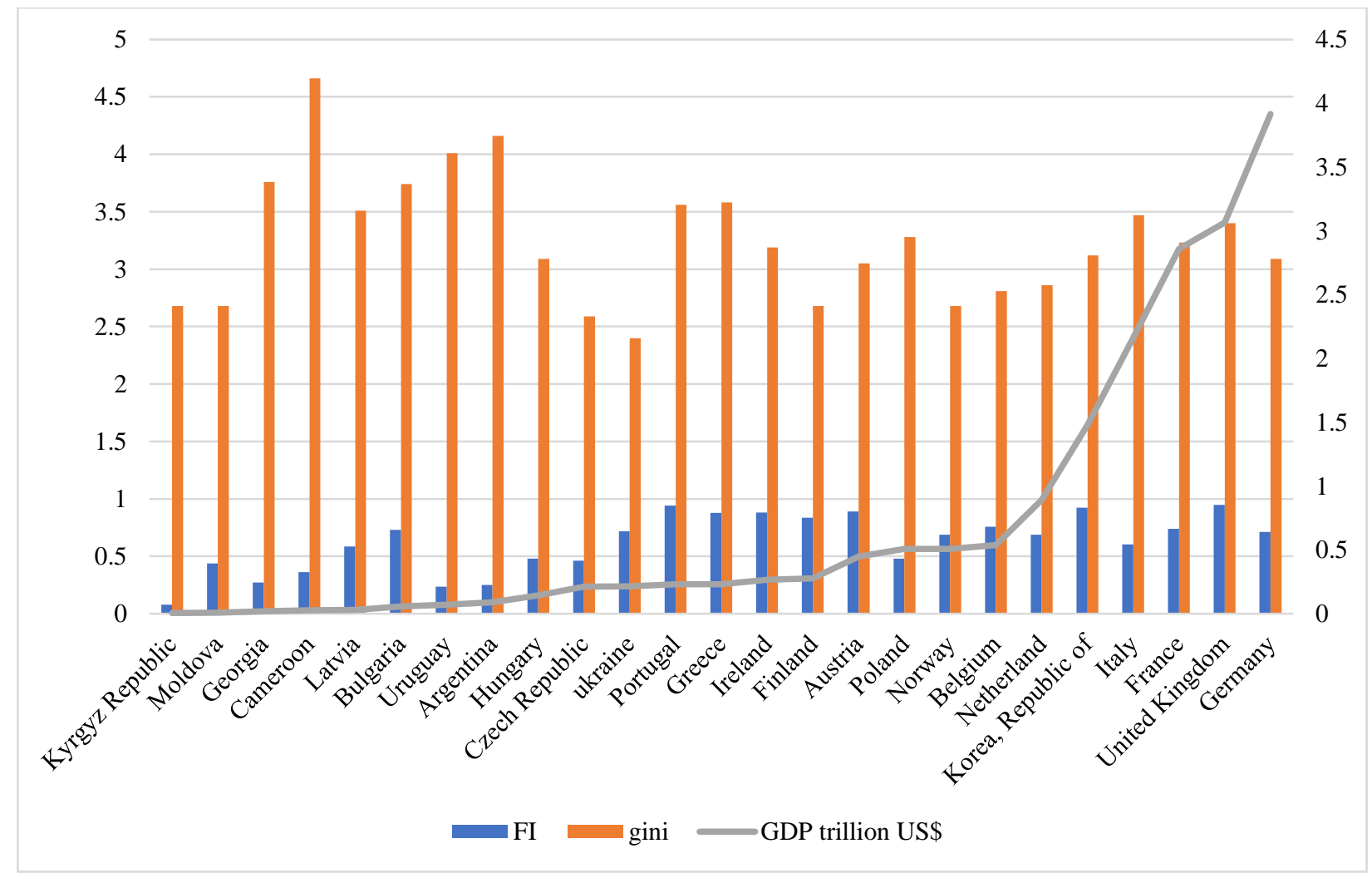

Source: Sarma (2015) and WDI (2014)

Figure 1. Financial Inclusion, Gini, and GDP of several countries 2014

Indonesia is one of developing countries that faces the problem of income inequality. Wicaksono et al. (2017) explains that education, wealth, and employment contribute to income inequality in Indonesia. This is also supported by the finding of Deyshappriya (2017) and Tridico (2017). Education plays an important role on income inequality since it determines individual's ability in earning income. Inequal distribution of education leads to inequal distribution of income. Wealth reflects financial ability of individual. Individuals with higher financial ability has more chance to several things, they are self-developed in education, certification, or business capital. Indonesia has been actively promoting financial inclusion, especially after the issuance of President Decree No. 822016 regarding national strategy on financial inclusion, which is then revised by President Decree No. 1142020 regarding national strategy on financial inclusion. There are several key points that is addressed in this decree. First, this national strategy is aimed to 1) create inclusive financial system that supported a deep and stable financial system, 2) foster economic growth, 3) alleviate poverty, and 4) decreasing income inequality to ensure community welfare. These aims 
would be reached through several ways; including increase of access on formal financial services, increase of financial literation and consumer protection, strengthen access for credit to small and micro enterprises, and the increase of digital financial product and services.

However, there are currently empirical debates on how financial inclusion affects income inequality. Park \& Mercado (2015), Fouejieu et al. (2020), and Le et al. (2019) argue that financial inclusion has negative effect on income inequality. It means that the higher the financial inclusion, the lesser income inequality will be. Financial inclusion policy is expected to reach lowincome community, so that they have higher ability to increase their income in many ways. Financial inclusion is expected to increase economic activity. Once economic growth is obtained, the opportunity of lowincome labor to obtain higher income is increasing. While, reducing barriers to financial services allow low-income group to benefit from several products provided by financial institution. It could help them to manage their income in more efficient way. Eventually, it is expected to alleviate poverty. As the poverty rate decreasing, the rate of inequality will also decrease ${ }^{2}$. Therefore, financial inclusion policy will eventually have a negative effect to income inequality indicator.

However, the mechanism explained above requires several condition and situation that eventually leads to decrease of income inequality. Those condition includes;

\footnotetext{
${ }^{2}$ However, there is also a debate on whether a decrease in poverty results in a decrease in inequality This debate is one of the reasons why the effect of financial inclusion on income inequality is not clear. As it is strongly evident that financial access has a huge impact to reduce poverty, but its impact on inequality is still ambiguous.
}

$75 \mid J u l i 22021$
1) financial services are used to develop real sector by enabling efficient allocation of capital and reducing borrowing and financing constraint, 2) economic growth as a result of access on financial services involves all economic sectors including agricultural sector, and other sector that mostly found in rural area, and 3) poor group benefit more from poverty alleviation through financial inclusion than non-poor group (Jauch \& Watzka 2016). This scenario will hardly result on the decrease of income inequality, or in the worst case, it might lead to the increase of income inequality. This mechanism is empirically supported by Jauch \& Watzka (2016), Aginta et al. (2018) and Ummah et al. (2015). There may be some factors which determines the effect of financial inclusion on income inequality. Therefore, the empirical conclusions may vary depending on the other factors.

Specifically, for the case of Indonesia, the discussion regarding this topic is centered on assessing the effectiveness of financial inclusion on income inequality (e.g. Ummah et al.2015; Aginta et al.2018). Meanwhile, the discussions fail to answer as to why the effect of financial inclusion on income inequality behaves in some way. Therefore, this study aims to contribute to the discussion by specifically analyze factor or channel which determine the behaviour of the effect of financial inclusion on income inequality. This paper proposes the term of financial structure to be one of the major factors that determines the effect of financial inclusion on income inequality in Indonesia.

In this study, financial structure refers to the intensity of microfinance in a region. Microfinance institution is deemed more accessible for low-income community. Therefore, a higher number of microfinance institution is expected to lower the level of inequality, as shown by Bangoura et al. (2016). Accordingly, this study attempts to 
fill the gap by further exploring as to why financial inclusion behaves in certain way towards income inequality by considering the financial structure aspect. Based on the previous studies and theories regarding development economics, it is hypothesized that financial inclusion, financial structure, and the interaction between these two variables has negative effect on income inequality.

Based on the explanation above, there are three objectives of this study. First, to estimate the effect of financial inclusion on income inequality in Indonesia. Second, to estimate the effect of financial structure on income inequality. Third, to estimate the effect of interaction between financial inclusion and financial structure on the relationship of financial inclusion on income inequality.

This study analysed the case on province level. The observation unit is 33 provinces in Indonesia (North Kalimantan is excluded). The data was recorded yearly from 2010 to 2020. Therefore, this study used static panel data model.

\section{LITERATURE REVIEW}

There are several studies that analyze the correlation between income inequality and economic indicators. Kuznets (1955) proposes a hypothesis regarding the correlation between income inequality and income per capita in a country. Kuznets (1955) argues that there is an "inverted-U" correlation between income inequality and income per capita. In this regard, when a country's income per capita is considered low, there will be a positive correlation between inequality and income per capita. However, when the income per capita reach a certain level of development, Gini coefficient will eventually decrease. Piketty (2014) then proposes new hypotheses regarding this topic. Instead of an inverted-U shape, Piketty
(2014) argues that there is an S-shaped correlation between income inequality and income per capita. That means, even when the Gini ratio is decreased, it will eventually increase again after income per capita reach certain point.

In regards of income inequality determinants, there are several studies that discussed the topic. Tridico (2017) identify the determinants of income inequality in OECD countries (25 countries from 1990 to 2013). The result showed that there are several factors that increase income inequality in OECD countries from 1990 to 2013, they are an increase of financialization, a weakening of trade unions, and an increase of labor flexibility. Malerba \& Spreafico (2014) identify the determinants of income inequality in 25 European countries (19952010), this study focused on finding structural determinants that affect income inequality. The result of this study showed that social mobility significantly affects income inequality as well as labor market institution. For addition, economic growth and social spending also plays a significant role in determining income inequality. Deyshappriya (2017) identify the determinants of income inequality in 33 Asian countries from 1990 to 2013. The results showed that there is an inverted-U shape relationship between gross domestic product and income inequality. Other than that, several factors that significantly affect income inequality were education, official development assistance, labor force participation, political risk, inflation, unemployment, and trade.

For the specific case of Indonesia, there are also several studies that identify determinants of income inequality. Silva \& Sumarto (2014) analyzed the nexus between economic growth and the dynamic of income distribution. Based on the findings, there is a proof that income inequality in Indonesia can 
be explained by the variation of expenditure based on education characteristic. Leuween \& Foldvari (2016) studied the development of inequality and poverty in Indonesia from 1932 to 2008. The study stated that based on the case of Indonesia during the observation period, the shift in industry played a significant role in the variation of income inequality. Prasetyo, Priyarsono, \& Mulatsih (2013) identified the infrastructure and its connection to growth and inequality in the border land of Indonesia. Based on the result, the study found that inequality in the border land of Indonesia is related to per capita growth and the labor in manufacturing sector.

The idea of financial inclusion is highly supported by several international developmental organizations as their research findings suggested a negative effect of financial inclusion on poverty and income inequality $^{3}$. Therefore, many countries implement this idea into their national policies in accordance with international guidelines (Soetiono \& Setiawan, 2018) ${ }^{4}$. However, based on literature, the implementation of financial inclusion policy would not always lead to the decrease of poverty and income inequality.

Financial inclusion policy that comes in the form of increasing several key targets such as bank number per population and credit (or financing) per population is expected to reach low-income community. Then, this low-income community will be expected to have higher ability in levelling up their income and it will lead to poverty alleviation. As the poverty rate decreasing,

${ }^{3}$ For example, World Bank, Asian Development Bank, International Monetary Fund, etc

${ }^{4}$ G20 Principles for Innovative Financial Inclusion, Financial Access Survey by World Bank that is followed by establishment of CGAP (Consultative Group to Assist the Poor) the rate of inequality will also decrease ${ }^{5}$. Therefore, financial inclusion policy will eventually have a negative effect to income inequality indicator. This mechanism is empirically supported by Park \& Mercado (2015), Neaime \& Gaysset (2008), Le et al. (2019), and Fouejieu et al., (2020).

Park \& Mercado (2015) examine the effect of financial inclusion on income inequality in Asia. This study used panel data analysis on 37 selected Asian countries. The research found that financial inclusion significantly reduces poverty and lowers income inequality. Fouejieu et al. (2020) analysed the effect of financial inclusion on income inequality in global level. The dataset includes both developed and developing countries from 2004 to 2015. This analysis highlighted the influence of macroeconomic indicator in a country on the effect of financial inclusion to income inequality. It also discussed gender gaps in financial inclusion. The result concluded that in global level, financial inclusion significantly reduced income inequality given the country's macroeconomic indicator. This research also revealed that there is currently inequal proportion of financial inclusion between men and women. Le et al., (2019) analysed the effect of financial inclusion on income inequality in transition economies. The dataset includes 22 countries that are considered transition economies from 2005 to 2015 . The result concluded that there is a negative and significant effect of financial inclusion on income inequality.

However, financial institution is profitoriented at its nature. Consequently, it allows

\footnotetext{
5 However, there is also a debate on whether a decrease in poverty results in a decrease in inequality This debate is one of the reasons why the effect of financial inclusion on income inequality is not clear. As it is strongly evident that financial access has a huge impact to reduce poverty, but its impact on inequality is still ambiguous.
} 
saving accounts to include all segments of community while credit account can only be afforded by bankable community. To be bankable, an entity needs to possess stable income, a sound financial report, and often own collateral. These requirements might not be able to be fulfilled by low-income community. Therefore, even under financial inclusion policy implementation, all people have access to saving, but not all people have access to credit from financial institution. Eventually, financial inclusion is considered to carry out money from low-income community and distribute it to the higherincome community. This scenario will hardly result on the decrease of income inequality, or in the worst case, it might lead to the increase of income inequality. This mechanism is empirically supported by Jauch \& Watzka (2016), Aginta et al. (2018) and Ummah et al. (2015) which are both analyzed the case of Indonesia.

Ummah et al. (2015) analyzed the correlation between financial inclusion and income distribution in Indonesia using province-level data. Using Panel Tobit regression, the analysis gave evidence that income distribution affected financial inclusion significantly and in a negative way. That means, the higher the income distribution, the lower the financial inclusion is. Following Granger causality test, it is revealed that income distribution affected financial inclusion but not vice versa. It means financial inclusion has no significant effect on income distribution.

Aginta et al (2018) investigated the link of financial inclusion and income inequality for 33 provinces in Indonesia. The novelty of this study was that it accommodates different characteristic of provinces in regards to their dominant economic activity. Therefore, the analysis was conducted by dividing 33 provinces into two types, they are mining and manufacturing-based provinces and 78|Juli 2021 agricultural-based provinces. This analysis was conducted using the Fixed Effect Panel Model. The result showed that at national level, financial inclusion did not have significant effect on income inequality. However, there were mixed results for the analysis in province level. In mining and manufacturing-based provinces, financial inclusion tends to have a negative impact on income inequality. Meanwhile, the same case did not happen for agricultural-based provinces. Therefore, it can be concluded that the dominant sector in the area of analysis matters as it gives a different result for the agricultural-based region and miningmanufacturing based region.

There are also other studies that found non-linear relationship between financial development (including financial inclusion) and income inequality. Greenwood \& Jovanovic (1990) analyzed the relationship between financial development and distribution of income using theoretical approach. This study found an inverse-U shape relationship. Then, Cantu, JaramilloGarza, \& Rosa, (2015) confirms the hypothesis of Greenwood \& Jovanovic (1990) by observing the influence of financial inclusion on income inequality for the case of Mexican municipalities in 2003. These findings showed that in the early stage of development, financial development increases inequality, but after a certain point of time, it will eventually decrease it. Tan \& Law (2012) analyzed finance-inequality nexus using the sample of 35 countries. The result showed that there is a U-shaped relationship between financial deepening and income inequality.

Other than those studies that directly assess the effect of financial inclusion on income inequality, there are several other studies that are related to this topic. First, the study conducted by Sarma \& Pais (2011). It analyzed the relation between financial 
inclusion and development indicators, including inequality. The study used crosscountry analysis. The result concluded that income inequality negatively affect financial inclusion in a country. However, this study did not discuss the effect of financial inclusion on income inequality.

Mushtaq \& Bruneau (2019) analyzed the effect of information and communication technology (ICT) on poverty and inequality. The mechanism explained in this study involved financial inclusion. The study argued that technology plays a vital role in financial inclusion that will eventually reduce poverty and inequality. The analysis used global data ranged between 2001 and 2012. The result showed that financial inclusion along with the development of information and communication technology significantly decreased income inequality at a global level.

Based on the theories explained above, financial inclusion affects income inequality through certain transmission. The transmission involves economic growth and poverty. Financial inclusion allows more access of financial services through reducing barriers. It leads to more option for efficient capital allocation of individuals and businesses. It then leads to the increase of economic activity. The increase of economic activity is expected to give more opportunity especially for low-income labor force as well as small enterprises. This could leads into poverty alleviation. As the income of poor people rises, the level of income inequality is expected to be reduced.

Microfinance institution is deemed more accessible for low-income community. Therefore, a higher number of microfinance institution is expected to lower the level of inequality, as shown by Bangoura et al. (2016), and Kai \& Hamori (2009). This nature of microfinance is expected to ensure the fulfilment of certain condition required for the transmission of financial inclusion to 79|Juli 2021 income inequality to actually happen. Therefore, microfinance plays a strategic role in the association of financial inclusion and income inequality. The effect of financial inclusion and income inequality might be different depends on the intensity of microfinance in a region.

Based on theoretical concepts and empirical evidence explained above, the framework of this study is demonstrated in Figure 2. The main focus of this study is the relationship between financial inclusion and income inequality. Therefore, in the figure, the full-arrow is administered for this. Meanwhile, the dotted line explains the transmission behind the relationship between those two variables. The intensity of microfinance is represented by financial structure. The relationship between financial inclusion and income inequality theoretically differs based on the intensity of microfinance. Therefore, financial structure is administered in this study as moderating variable that interact with financial inclusion to affect income inequality.

In the transmission mechanism (the dotted line), the intensity of microfinance is put in the relationship between financial inclusion and GRDP as it is associated with how financial inclusion could affect economic activities. Financial structure is also put into the dot linked financial inclusion and poverty as the effect of financial inclusion on poverty might depends on the value of microfinance intensity. Even though the main focus of this study is the relationship between financial inclusion and income inequality (full line), however, this study also observes the relationship between financial inclusion and variables in the transmission mechanism that are GRDP and poverty as to obtain more information regarding how this transmission mechanism occurred in empirical case. 
Figure 2 also demonstrates hypotheses of the research. H1 represents the hypothesis regarding the relationship of financial inclusion and income inequality. $\mathrm{H} 2$ represents the hypothesis regarding the effect of financial structure on the relationship between financial inclusion and income inequality. H3 represents the hypothesis regarding the relationship between financial inclusion and GRDP. H4 represents the hypothesis regarding the effect of financial structure on the relationship between financial inclusion and GRDP. H5 represents the hypothesis regarding the relationship between financial inclusion and poverty. H6 represents the hypothesis regarding the effect of financial structure on the relationship between financial inclusion and income inequality. The odd numbered hypothesis represents the relationship between financial inclusion and three different variables. Meanwhile, the even numbered hypothesis represents interaction between financial inclusion and income inequality.



Source: Author

Figure 2. Conceptual Framework

\section{EMPIRICAL FRAMEWORK}

Based on theoretical framework that was explained in the previous chapter, we arrange the empirical framework to conduct this study. This chapter explained how the model is build based on the objective of the study. This chapter also specify the econometrics method used in this study, along with data and data source. In brief, this study analyses the case of Indonesia. The model used in this study is panel data model with provinces as the cross-section unit and the year 2010-2020 as the time series unit. 
The dependent variable is income inequality, and the variable of interest is financial inclusion index and financial structure. Other than that, there are also control variables which hypothetically affect income inequality.

Based on the available dataset, statistical method that could be used to analyze is panel data regression analysis. Panel data regression analysis is used in this study to observe the behavior of the data, especially unique behavior of each province in Indonesia, since they have different characteristic. Macro panel data model was used in this study since the data was collected on province level with 33 units of observation and a total of 11 years.

The term financial inclusion or financial structure written in this paper is meant to refer to the financial sector as a whole. However, the analysis is administered to the banking sector only, including the measurement of financial inclusion that involved only indicators in banking sector. Previous studies argue that this is justified as banking sector usually takes a large portion in the whole financial sector and plays a significant role in it. For the case of Indonesia, it is confirmed as banking sector takes up to $57 \%$ of the whole portion of financial sector (SNKI, 2018).

\section{Financial Inclusion Index}

There are several ways to measure financial inclusion. The most upgraded version is the weighted indexes that was further developed from the equally-weight index by Sarma (2008). However, there are different ways of weighting in regards of financial inclusion index. Wang \& Guan (2017) developed the index formerly introduced by Sarma (2008). While Sarma (2008) introduced an index with no weight (every component has equal weight), Wang \& Guan (2017) developed an unequal $81 \mid$ Juli 20221 weighting index. The weight that is put in the components of the index was based on the coefficient of correlation. Meanwhile, Camara \& Tuesta (2014) adapting Principal Component Analysis (PCA) to the measurement of financial inclusion. This study attempted to use the index formulated by Wang \& Guan (2017) since it already considers weighting of each indicator and dimension. The index formulated by Camara \& Tuesta (2014) also considered weighting. However, the PCA method used in this study was two-stage PCA. This method could not be applied to the dataset whose dimension consists of only one indicator. Therefore, the index of Wang \& Guan (2017) is deemed more suitable for this study.

The index of Wang \& Guan (2017) and Camara \& Tuesta (2014) divided the component of financial inclusion into dimensions. To make these two indexes comparable, we use the same dimensions for both indexes, they are the dimension of usage and the dimension of access. For crosscountry analysis, previous studies used number of branch offices per 1000 adults, percentage of account possession for adults, and ATM per 100,000 adults as the indicator of dimension of access. Then, they used deposit as percentage of GDP, and loan as percentage of GDP for dimension of usage. In this study, dimension of access is number of offices per 1000 adults, while dimension of usage consists of two indicators, the thirdparty fund per GRDP and credit per GRDP. These indicators were chosen by adjusting the concept of access and usage in financial inclusion index and the relevant available data for province level. For dimension of access, ATM data and account possession data is not available for province level, therefore, in this study, the indicator of dimension of access is only branch offices per 1000 adults. 
Equation (1) demonstrated the calculation of each indicator. With $x_{i j}$ denotes the value of indicator $j$ in dimension $i$. $A$ denotes actual value of corresponding indicator, $M$ denotes maximum value, while $m$ denotes minimum value. Equation (2) demonstrated the compilation of each indicator into one dimension. $d_{i}$ denotes the value of dimension $i, w$ denotes weight of each indicator, while the index $1-n$ denotes the number of indicator (there are $n$ indicators in each dimension). Equation (3) demonstrated the compilation of each dimension into one index of financial inclusion. The weight in this equation calculatedusing Coefficient of Variance.

$$
\begin{aligned}
& x_{i j}=\frac{A_{i j}-m_{i j}}{M_{i j}-m_{i j}} . \\
& d_{i}=1-\frac{\sqrt{w_{i 1}^{2}\left(1-x_{i 1}\right)^{2}+w_{i 2}^{2}\left(1-x_{i 2}\right)^{2}+\cdots+w_{i n}^{2}\left(1-x_{i n}\right)^{2}}}{\sqrt{w_{i 1}^{2}+w_{i 2}^{2}+\cdots+w_{i n}^{2}}} \\
& F I I=1-\frac{\sqrt{w_{1}^{2}\left(1-d_{1}\right)^{2}+w_{2}^{2}\left(1-d_{2}\right)^{2}}}{\sqrt{\left(w_{1}^{2}+w_{2}^{2}\right)}} .
\end{aligned}
$$

\section{Financial Structure}

Financial structure in this study focused on the concentration of microfinance institutions relative to general financial institutions. Microfinance institution specialized in providing financial needs of small individuals and business with limited asset. Microfinance institutions includes rural banks (Bank Perkreditan Rakyat), Baitul Maal Wat Tamwil (BMT), etc. Meanwhile, general financial institution provides various financial product targeted for broader customer. General financial institution includes general banks (Bank Umum), Insurance, Pension Fund, Venture Capital, etc. Microfinance institution is deemed more accessible for low-income community. Therefore, a higher number of microfinance institution is expected to lower the level of income inequality, as shown by Bangoura et al. (2016), and Kai \& Hamori (2009). Nevertheless, as explained earlier, the approach of comparing microfinance intensities across observations using the ratio of microfinance institution to macro finance institution (simplified by 'financial structure') has not been done to explain the effect of financial inclusion on income inequality. Yet, it does not necessarily negate the possible existence of pure effect of financial structure on income inequality.

Measurement of financial structure is based on several literature. However, the term 'financial structure' itself has a broad meaning depends on the discussion topic. A firm's financial structure could not be compared by a country's or a region's financial structure. In regard to a region's financial structure, there are several definitions which are derived from relevant literature. Tang \& Yao (2018) defined financial structure from two different perspectives. First, the financial structure of a country by means of its orientation. It is defined by either market-oriented or banking oriented. The indicator of this structure is measured by the ratio of stock market value and private bank loan. Second, the financial market of a country by means of its financial sector development compared to its GDP. 
The indicator of this structure is measured by sum of the stock market value and bank credit divided by GDP. Liu \& Zhang (2018) used a similar definition of the financial structure by Tang \& Yao (2018) as they compared market-based view and bank-based view.

Based on those existing literature, financial structure in this study is measured by composition between microfinance and general finance. The indicator is demonstrated in the form of ratio. In this research, financial institution is simplified into banks as it deemed more familiar for the larger segment of people and more inclusive (SNKI, 2018). However, the indicators of bank itself is varied. This study used the value of third-party fund and credit of rural bank to represent micro-banking, and it used third-party fund and credit of general banking. These two indicators are used because they are relevant and available for province level data.
These two indicators are indexed into one value using the indexing method of Sarma \& Pais (2011) as explained in equation (4). The sign $i_{j}$ denotes the value of indicator $j$. There are two indicators in this case; they are third party fund and credit of each banking sector (micro banking and general banking). The sign $w$ denotes weight, $A$ denotes the actual value of indicator, $M$ denotes maximum value of indicator, while $m$ denotes minimum value of indicator. Then, both values of indicator are compiled following equation (5). $y$ indicates the compilation value. There are two values of $y$ that are being calculated. They are, $y$ for micro-banking and $y$ for general banking. The final step to calculate the financial structure $F S$ of an observation unit is by forming a ratio between these two variables as in equation (6). Micro-banking sector is proxied by rural bank while general banking is proxied by general bank.

$$
\begin{aligned}
& i_{j}=w_{j} \frac{A_{j}-m_{j}}{M_{j}-m_{j}} \ldots \ldots \ldots \ldots \ldots \ldots \ldots . . \\
& y=1-\sqrt{\frac{\left(w_{1}-i_{1}\right)^{2}+\left(w_{2}-i_{2}\right)^{2}}{w_{1}^{2}+w_{2}^{2}}} . \\
& F S=\frac{y_{\text {microbanking }}}{y_{\text {generalbanking }} \ldots \ldots \ldots \ldots} .
\end{aligned}
$$

\section{Empirical Strategy}

The main objective of the study is to examine the effect of financial inclusion on income inequality by considering the effect of financial structure. This study used panel data model with interaction variable to accommodate the analysis. The model is formed in accordance to conceptual framework as explained in the previous chapter. The dependent variable is income inequality, while the independent variable is financial inclusion, and the interaction of financial inclusion and financial structure. Therefore, panel data model is specified in equation 7. Financial structure is included in the specification to avoid confounding variable. GRDP and poverty is included in the equation as they are variables which determines the transmission mechanism of financial inclusion and income inequality. Therefore, these two variables are also included to avoid confounding. Confounding happens when there is an exaggerated effect or spurious correlation between two 
variables. Sometimes, it happens because there are several variables that actually affect dependent variable but they are not included as independent variable in the equation.

Control variable $(Z)$ is a set of other factors that affect income inequality. These control variables are including GRDP (Beck, 2006), Human Development Index, Government Expenditure (Refqi \& Hidayat, 2019), Technology (Mushtaq \& Bruneau, 2019), (Sarma \& Pais, 2011), Literacy (Sarma \& Pais, 2011), Export, Import, Inflation (Aginta et al 2018), per capita income (Chrisyanto 2006), Democracy Index, and Unemployment (Malerba \& Spreafico 2014).

Meanwhile, the interaction between financial inclusion and financial structure reflected the interaction between the operational of general bank and rural bank.
This interaction could take form as linkage program. It is a cooperation scheme between general bank and microfinance institution. In this scheme, general bank expands their credit customer to middle-low-income community through microfinance institutions. Linkage programs consist of executing, channeling, and joint financing. Executing means general bank cannot decide where the fund go, while channeling means general bank decided where the fund go. Meanwhile, joint financing means that it consists of both from general bank and microfinance institution. Therefore, we used interaction variable between financial inclusion and financial structure. The usage of interaction variable to accommodate this scheme is supported by the study of Ghosh (2013).

$$
G I N I_{i, t}=\theta_{0}+\theta_{1} F I_{i, t}+\theta_{2} F S_{i, t}+\theta_{3}\left(F I_{i, t} * F S_{i, t}\right)+\theta_{4} G R D P_{i, t}+\theta_{5} P_{o v} v_{i, t}+\boldsymbol{\theta}_{\mathbf{6}} \boldsymbol{Z}_{\boldsymbol{i}, \boldsymbol{t}}+
$$

$\epsilon_{1, i, t}$

Beside the main equation demonstrated in equation 7 , this study also examines the transmission mechanism of financial inclusion on income inequality. Based on the transmission mechanism, financial inclusion affect poverty through increasing economic activity (equation 8).
Meanwhile, equation 9 demonstrated the link between financial inclusion and GRDP. These two models are included to test whether the transmission mechanism that involve poverty and GRDP are empirically supported or not.

$$
\begin{aligned}
& \operatorname{Pov}_{i, t}=\alpha_{0}+\alpha_{1} F I 1_{i, t}+\alpha_{2} F S_{i, t}+\alpha_{3}\left(F I 1_{i, t} * F S_{i, t}\right)+\boldsymbol{\alpha}_{\mathbf{4}} \boldsymbol{Z}_{\boldsymbol{i}, \boldsymbol{t}}+\epsilon_{2, i, t} \ldots \\
& G R D P_{i, t}=\mu_{0}+\mu_{1} F I 1_{i, t}+\mu_{2} F S_{i, t}+\mu_{3}\left(F I 1_{i, t} * F S_{i, t}\right)+\boldsymbol{\mu}_{\mathbf{4}} \boldsymbol{Z}_{i, \boldsymbol{t}}+\epsilon_{3, i, t}
\end{aligned}
$$

Interaction variables in equation (7),

(8), (9) indicates that financial inclusion affects income inequality contextual to financial structure. Financial structure can either strengthen or weaken the effect of financial inclusion to income inequality. To determine how financial structure affect this correlation, we can take partial differentiation of equation (7) with respect to financial inclusion variable. The differentiation set out as follows: 


$$
\frac{\partial G I N I_{i, t}}{\partial F I_{i, t}}=\theta_{1}+\theta_{3} F S_{i, t}
$$

The effect of pure financial inclusion variable is reflected by $\theta_{1}$, meanwhile, the effect of financial inclusion variable interacted with financial structure is reflected by $\theta_{3}$. Therefore, the term demonstrated in equation (25) is the total marginal effect of financial inclusion on income inequality. The gradient of $F S_{i, t}$ or the sign of $\theta_{3}$ indicates the role of financial structure on the effect of financial inclusion to income inequality. If the sign is positive, it means higher value of financial structure strengthen the effect of financial inclusion on income inequality. If the sign in negative, then a higher value of financial structure weakens the effect of financial inclusion on income inequality.

There are several tests that needs to be conducted before and after estimation. LM-test was used to decide appropriateness between Pooled Least Square Model or Random Effect Model. Hausman test was used to decide appropriateness between Random Effect Model and Fixed Effect Model. Each equation was tested to determine the most appropriate static panel data analysis. After that, robustness check was done by dividing the sample into subgroups and re-estimate the models. The division was based on characteristic of provinces as the unit of observation in this study. Some of them was GRDP, HDI, FI, and FS. However, only the results of subgrouping based on HDI that was shown in this article, because the other sub-grouping variables do not show any different results with all-provinces analysis.

\section{Data and Sources}

In the attempt of developing the above models, several datasets are needed. They mainly consist of financial, economic, and demographic sector data. Financial sector data are obtained from the Indonesian Banking Statistic of Financial Services Authority (SPI-OJK), while economic and demographic sector data are obtained Statistic Centre Board (BPS). The data are in the form of annual data ranged from 2010 to 2020 and includes 33 provinces in Indonesia. The specific information regarding data and data source is detailed in Table 1.

The dependent variable is income inequality. It is proxied by Gini ratio. The variable of interest is financial inclusion and financial structure. To obtain these variables, there are several datasets that are needed, they are third party fund, credit, number of offices, number of accounts, either for general bank or rural bank. Meanwhile, for the control variables, this study used GDRP (Beck, 2006), Human Development Index, Government Expenditure (Refqi \& Hidayat, 2019), Internet Usage (Mushtaq \& Bruneau, 2019), (Sarma \& Pais, 2011), unemployment (Prasetyo, Priyarsono, \& Mulatsih, 2013), and Literacy (Sarma \& Pais, 2011). There are also the data of export, import, investment, per capita income, democration index, consumer price index, and investment.

Meanwhile, for the model that analyses transmission mechanism (equation 8 and equation 9), the dependent variable is poverty and economic activity. Poverty is proxied by $\mathrm{P} 2$ which indicates income inequality between poor people. Meanwhile, economic activity is proxied by gross regional domestic product (GRDP). 
Table 1. Data and Sources

\begin{tabular}{|c|c|c|}
\hline Data & Unit & Data Source \\
\hline Third-Party Fund of General Bank & Billion rupiah & \multirow{5}{*}{$\begin{array}{l}\text { Financial Services Authority } \\
\text { (Otoritas Jasa Keuangan) }\end{array}$} \\
\hline Third-Party Fund of Rural Bank & Billion rupiah & \\
\hline Financing/Credit of General Bank & Billion rupiah & \\
\hline Financing/Credit of Rural Bank & Billion rupiah & \\
\hline Number of general bank Office & Unit & \\
\hline Population of Adult & Person & \multirow{2}{*}{ CEIC } \\
\hline Export & Million Rupiah & \\
\hline Import & Million Rupiah & \multirow[t]{7}{*}{ CEIC } \\
\hline Gross Regional Domestic Product & Million rupiah & \\
\hline Human Development Index & Index & \\
\hline GINI ratio & Index & \\
\hline Democracy Index & Index & \\
\hline Government Expenditure & Million rupiah & \\
\hline Cellphone usage & Ratio & \\
\hline Literacy & Percentage & \multirow{7}{*}{$\begin{array}{l}\text { Statistic Bureau (Badan Pusat } \\
\text { Statistik) }\end{array}$} \\
\hline Investment & Million Rupiah & \\
\hline Per capita Income & Rupiah & \\
\hline Unemployment & Percentage & \\
\hline Democration Index & Index & \\
\hline Consumer Price Index & Index & \\
\hline Poverty Severity Index (P2) & Index & \\
\hline
\end{tabular}

\section{RESULTS AND DISCUSSION}

\section{General Description}

Financial inclusion index in this study is measured using two different methods. The first measurement $(\mathrm{F} 1)$ is financial inclusion index by Wang \& Guan (2017). The index is the further development of financial inclusion index by Sarma \& Pais (2011) that does not consider weighting of variables. The index of Wang \& Guan (2017) included weighting. Figure 3 graphically demonstrates the measurement result of FI. The bars in the figure reflected the average yearly value of each observation (province) that is measured from ten years data (2010 to 2020).

Based on Figure 3 the highest value of FI is attributed to 11th observation, followed by 17th observation. 11th observation is identified as DKI Jakarta while 17th is identified as Bali Province. Both provinces are indeed areas with high circulation and transaction of money since the first one is the country's capital city while the second one is the country's most famous international tourism destination. The circulation and transaction of money 
involved many financial institutions. Therefore, it is very likely that both provinces has the highest financial inclusion index among any other provinces in Indonesia. Figure 4 Demonstrates the value of financial structure (FS) variable. This variable reflected the ratio of microbanking to general banking. The higher value of FS in an area, means the higher the value of microbanking's aspect per its general banking aspect. That means, the activities of microbanking in this particular area is considered higher than the other areas that has lesser FS value.

The value of FS in the bars is the annual average of each observation's FS that is measured from ten years data (2010-
2020). Based on the figure, several observations that have considerably high FS value are the $8^{\text {th }}, 13^{\text {th }}, 14^{\text {th }}, 17^{\text {th }}$ and $30^{\text {th }}$ observation, identified as Lampung, Central Java, D.I. Yogyakarta, Bali, and Maluku Province. These provinces are considered to have higher microbanking activities per general banking activities compared to the other provinces. Meanwhile, several observations that have considerably low FS value are the $7^{\text {th }}, 11^{\text {th }}, 23^{\text {rd }}$ and $29^{\text {th }}$ observation, identified as Bengkulu, DKI Jakarta, East Kalimantan and West Sulawesi Province. It means, microbanking activities per general banking activities in these provinces are considered low among any other provinces in Indonesia.

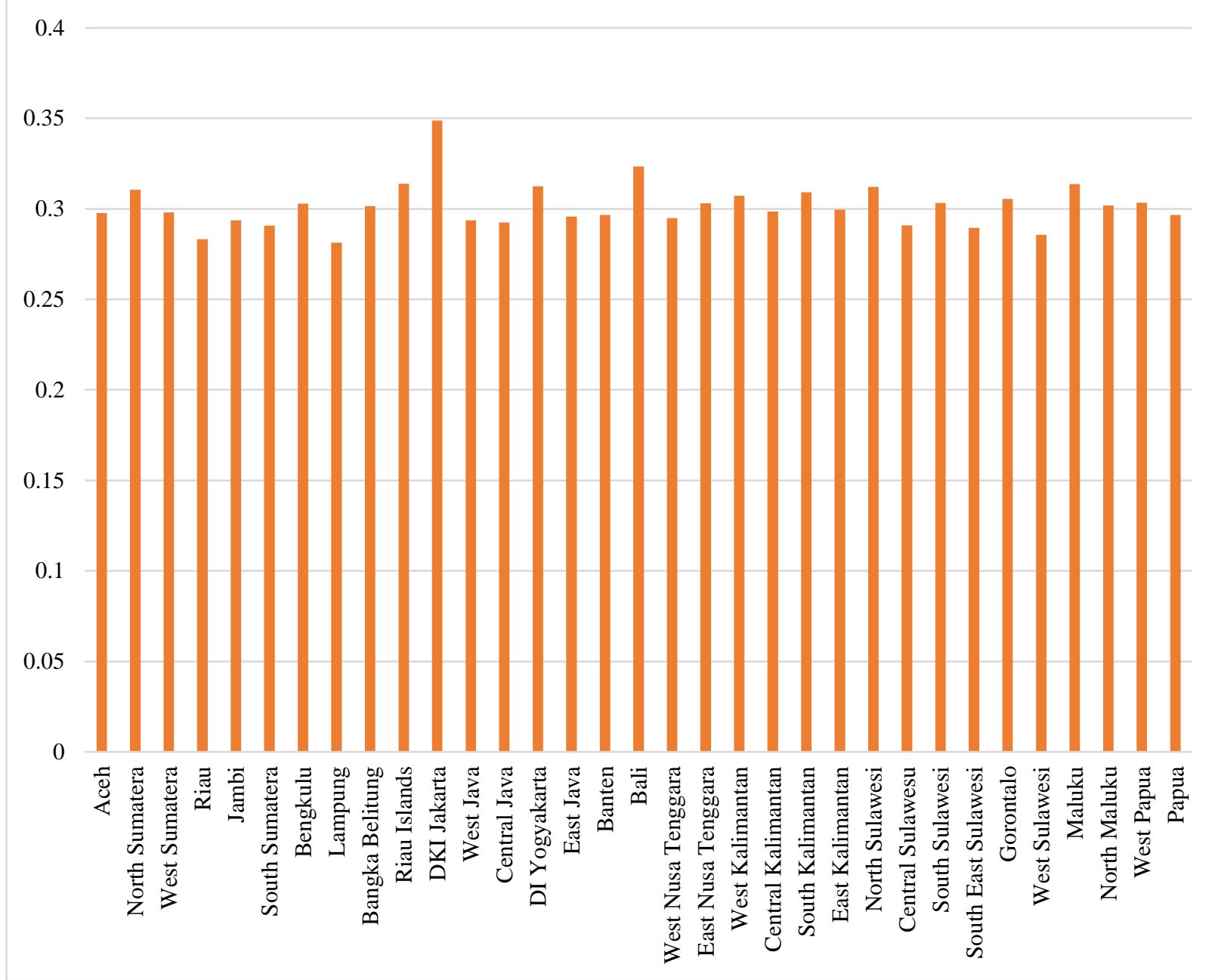

Source: OJK (processed)

Figure 3. Financial Inclusion across observation 
DKI Jakarta, specifically has the lowest value of FS, meanwhile, it has the highest value of FI. That means, financial activities in DKI Jakarta are mostly handled by general banking or financial institution instead of microbanking or microfinance institution. Meanwhile, Bali Province which has the second-highest value of FI turn out to also have second-highest value of FS. It means, even if both provinces have the highest FI among any other provinces in Indonesia, but its value of FS is completely opposite of each other. While DKI Jakarta's financial inclusion is mostly contributed by general banking and any other big financial institution, financial inclusion in Bali is mostly constructed by microbanking or any other microfinance institution in general.

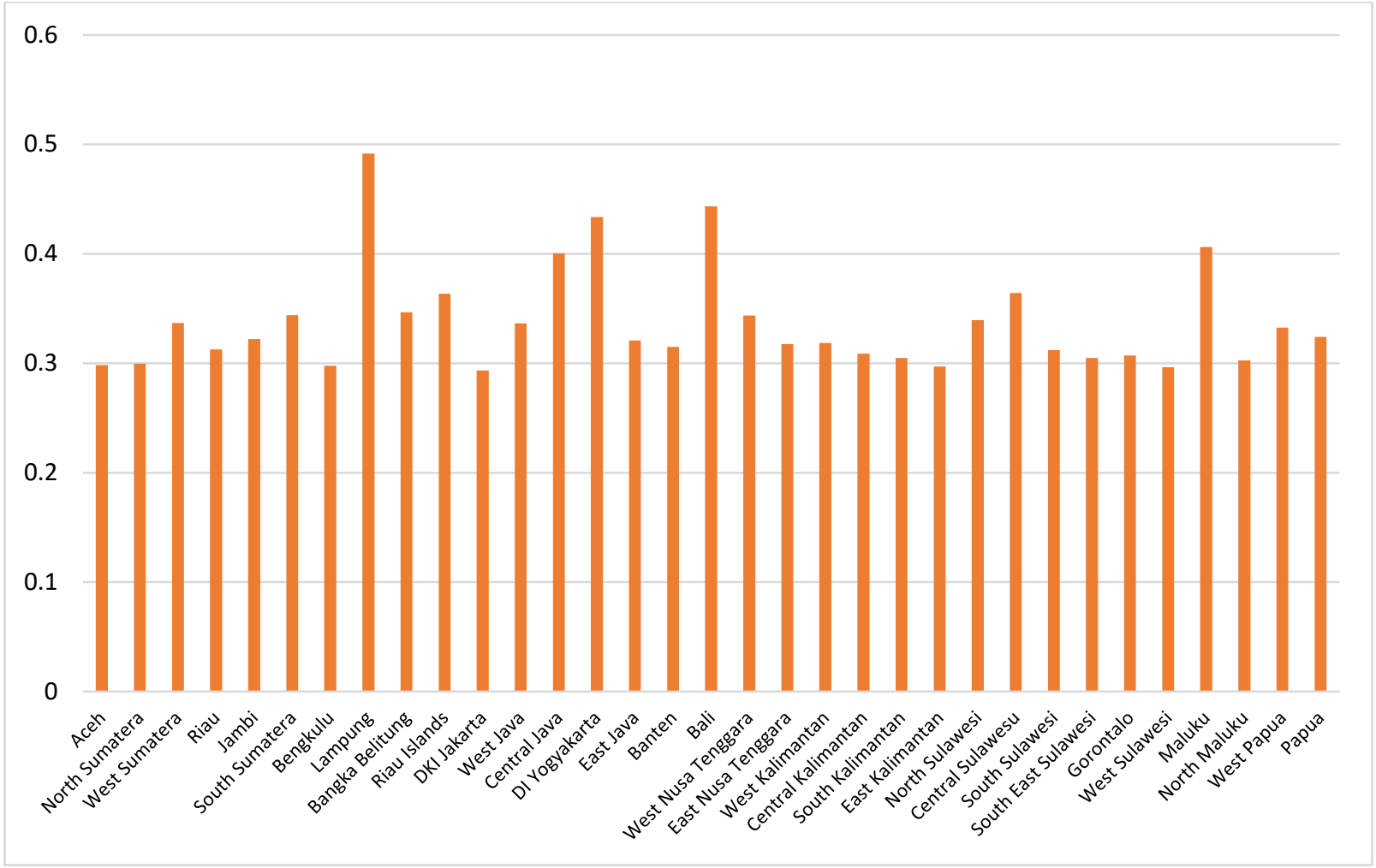

Source: OJK (processed)

Figure 4. Financial Structure across observations

Based on 2020 data, DKI Jakarta's third-party fund of rural bank is recorded to be 2495,046 billion rupiah, and its credit is 2051,444 billion rupiah. Meanwhile, Bali's third-party fund of rural bank is recorded to be 11919,88 billion rupiah, and its credit is 11521,73 billion rupiah. Bali's value of rural banking transaction is more than four times of Jakarta. Figure 5 demonstrated the contradiction between the case of DKI
Jakarta and Bali Province. Based on the scatter plot formed by the value of FI and FS in both provinces, it is concluded that there is negative correlation between financial inclusion and ratio of microbanking activities in DKI Jakarta. Meanwhile, positive correlation between financial inclusion and ratio of microbanking activities is found in Bali Province. 


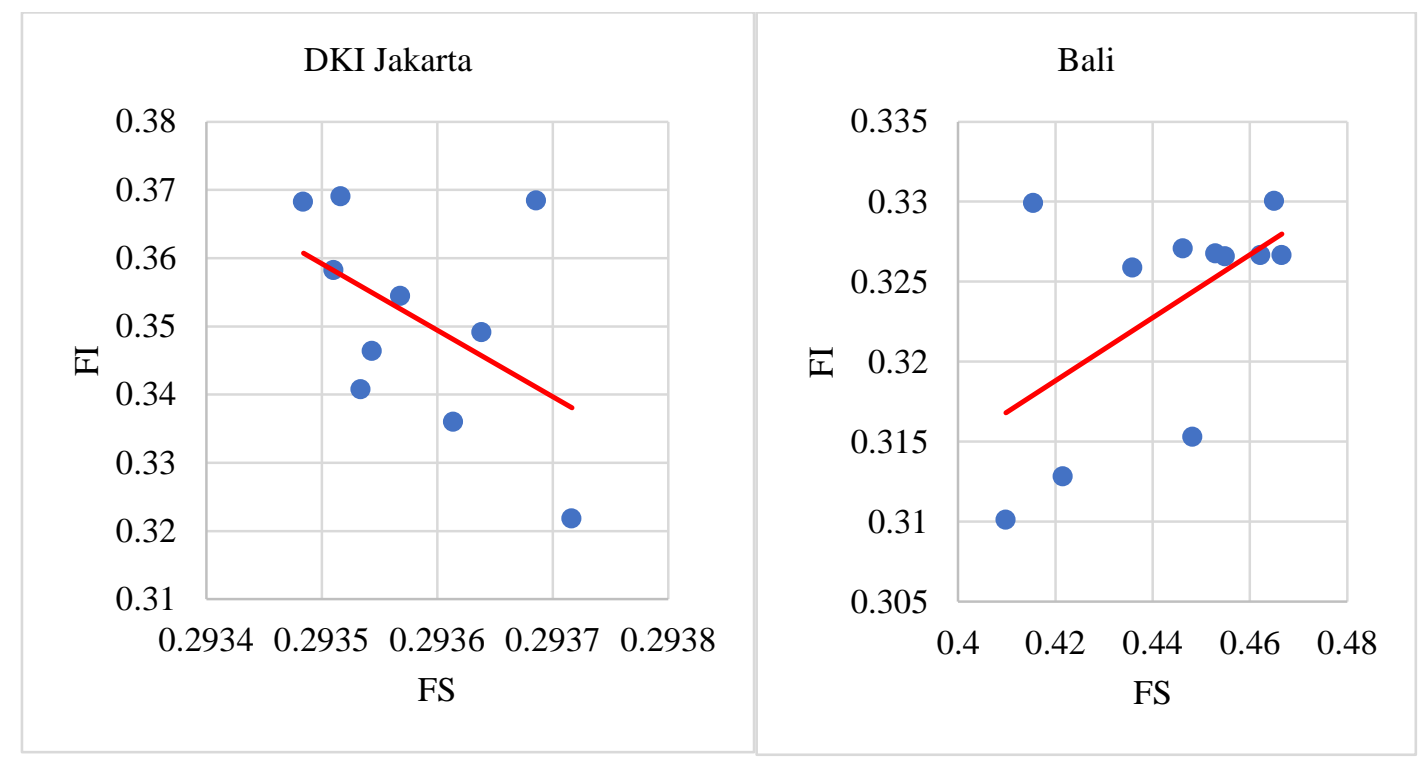

Source: OJK, CEIC, \& BPS (Processed)

Figure 5. Comparison of FI-FS relationship, Jakarta VS Bali

\section{Graphical Analysis}

The main objective of this study is to observe the correlation between financial inclusion and income inequality as well as financial structure and income inequality. However, two other indicators are added to the analysis to further analyse the transmission mechanism. Therefore, the scatter plot displayed in this study is not limited to the plot between income inequality (by Gini ratio) and financial inclusion index or income inequality and financial structure. Instead, it includes scatter plot between financial inclusion index and poverty, financial inclusion index and GRDP, financial structure with poverty and financial structure with GRDP.

Figure 6 demonstrated the scatter plot between FI and Gini, FI and poverty, FI1 and GRDP. The axis reflected FI while the ordinate reflected Gini, GRDP, and poverty. Based on the figure, FI and Gini has positive correlation. That means, the greater the financial inclusion index, the greater the income inequality will be. Graphical analysis cannot confirm the significance of the effect; however, it can give a brief idea on how the data behave in its nature. And positive correlation between financial inclusion and income inequality that is demonstrated by the graph gives a brief idea that financial inclusion in Indonesia is not associated with lower income inequality, but rather associated to even higher income inequality. This result supports the second microfoundation argument that financial inclusion might only gather money from all segments of people while still distribute it discriminatively. In fact, saving account has simpler requirement than credit account.

FI and GRDP demonstrated positive correlation. That means, the higher the financial inclusion in a province, the higher its production will be. The positive correlation between financial inclusion and production indicates that economic activities in a region performs better when the people of this particular region have more access to financial product and is able to use them. This indication gives prove that financial development plays a significant role in economic development as once stated by Beck et al (2006).

FI and poverty demonstrated negative correlation. It means, the higher the financial inclusion, the lesser the poverty will be. The 
significance of this negative correlation between financial inclusion and poverty cannot be confirmed using graphical analysis. However, it indicates that the increase of access to financial product and usage of the product in a region is associated with lowering poverty in the corresponding region. This indication gives a brief idea that even if financial inclusion cannot solve the problem of inequality, it is at least moving in line with the objective of poverty alleviation.

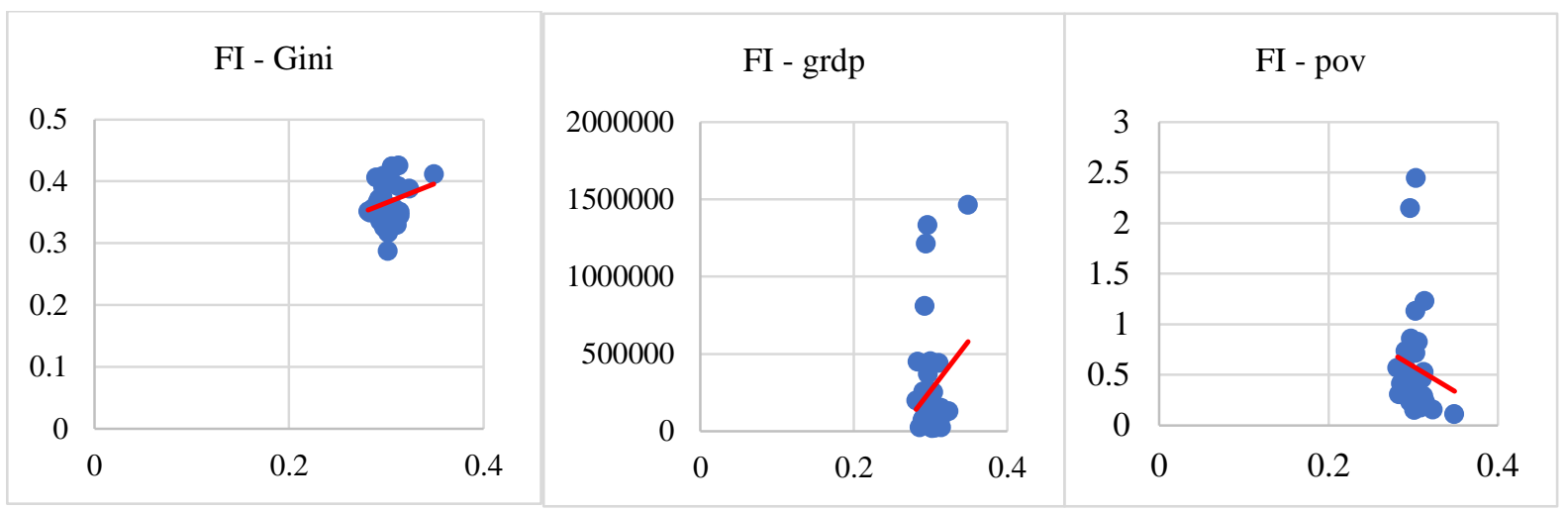

Source: OJK, CEIC, \& BPS (Processed)

Figure 6 Scatter plot between financial inclusion index and dependent variables

\section{Estimation Result for All Provinces}

Table 2 summarizes the estimation result for FI index by Wang \& Guan (2014). The main objective of this study is to analyse the correlation between financial inclusion and income inequality, financial structure to income inequality, and possible correlation between financial inclusion and financial structure. However, the estimation is not limited to those variables. The estimation also includes the other macro variables, GRDP and poverty. These variables are analysed for comparison to Gini and to give further idea about possible scenarios in regards of these variables.

Other than these main variables, the estimations also include several other control variables. The consideration of those variables is based on previous studies. The variables include literacy (lit), human development index (hdi), export (x), import (im), government expenditure (gex), consumer price index (cpi) that reflects inflation, investment (inv), unemployment (un), democration index (di), and cell-phone usage (hp).

Based on the result summarized in table 2, FI and FS does not significantly affect Gini ratio. For model with poverty as dependent variable, FI does not significantly affect poverty. For model with GRDP as dependent variable, FS, and interaction between FI and FS significantly affect GRDP. Meanwhile, FI does not significantly affect GRDP.

In the GRDP model, financial structure significantly affects GRDP in positive sign. That means, the increase of FS by $1 \%$ leads to the increase of GRDP by $2.04 \%$. Meanwhile, the interaction between FI and FS (FI1FS) showed negative sign. That means, the interaction between financial inclusion and financial structure weakens the effect of financial inclusion on GRDP. However, it could also mean that the interaction also weakens the effect of financial structure on GRDP. Based on the result, it is concluded that while the intensity of microbanking affect GRDP in positive way, however, the interaction between 
financial inclusion (from general bank) and microbanking intensity through linkage programs weaken the effect. That means, linkage program might hinder production. This case possibly happened through inefficient bureaucracy that prevent microbanking from funding enterprises which contributes to GRDP.

On the other hand, several control variables have significant effect on Gini, poverty, and GRDP. In all models, HDI has negative and significant effect on Gini and poverty, while it has positive and significant effect on GRDP. It gives prove that human resource factor plays an important role in increasing production, poverty alleviation and reducing income inequality. This finding is consistent with the result of Refqi \& Hidayat (2019).

Government expenditure has positive and significant effect on Gini. It indicates that government programs have not met the goal to reduce income inequality. This result gives a brief idea that while government expenditure gives positive impact on the income of poor people (through transfer, aids, etc), it also gives chance to non-poor people. Imbalance effect on these two different groups might lead to the increase of income inequality. This result is consistent with the finding of Refqi \& Hidayat (2019).

Investment has positive and significant effect on Gini and GRDP. That means, investment could lead to the increase of production. However, the increase of production does not necessarily in line with the decrease of income inequality. This result indicates that most of the investment might benefitted more on non-poor group than on poor group of people. This might be the case since investor prefers more guaranteed return. And guaranteed return is often associated with capability which is measured by formal indicators, such as proper financial report and collateral. Meanwhile, those requirements are not likely to be affordable for poor group of people. This finding is consistent with the result of Fazaalloh (2019).

Meanwhile, cellphone usage demonstrated negative and significant effect on poverty. The data of cellphone usage in a province was obtained by measuring the ratio of household with cellphone and actively using it to total number of households in a province. This measurement indicates the intensity of technology which represented by the usage of cellphone among households in a province. That means, the development of technology plays an important role in reducing poverty. This result is consistent with the finding of Mushtaq \& Bruneau (2019). However, cellphone usage affect Gini ratio in positive sign. That means, even when cellphone usage has an ability to alleviate poverty, but it appear to also increase income inequality. It gives a brief idea that cellphone usage for non-poor group help them increase their income more than it does to poor-group.

Table 2. Regression result

\begin{tabular}{lrrr}
\hline \multirow{2}{*}{ Independent Variable } & \multicolumn{3}{c}{ Dependent Variables } \\
\cline { 2 - 4 } & \multicolumn{1}{c}{ Gini } & Poverty & \multicolumn{1}{c}{ GRDP } \\
\hline FI & 0.700 & 20.340 & 1.730 \\
& $(1.008)$ & $(13.794)$ & $(1.198)$ \\
FS & 0.509 & 20.561 & $2.040^{*}$ \\
& $(0.922)$ & $(12.761)$ & $(1.108)$ \\
fi1fs & -1.562 & $-69.299^{*}$ & $-6.481^{*}$ \\
& $(3.033)$ & $(41.880)$ & $(3.637)$
\end{tabular}




\begin{tabular}{|c|c|c|c|}
\hline \multirow{2}{*}{ Independent Variable } & \multicolumn{3}{|c|}{ Dependent Variables } \\
\hline & Gini & Poverty & GRDP \\
\hline \multirow[t]{2}{*}{ lngdrp } & 0.011 & & \\
\hline & $(0.017)$ & & \\
\hline \multirow[t]{2}{*}{ pov } & -0.003 & & \\
\hline & $(0.004)$ & & \\
\hline \multirow[t]{2}{*}{ lit } & 0.000 & $0.088 * * *$ & -0.003 \\
\hline & $(0.002)$ & $(0.025)$ & $(0.002)$ \\
\hline \multirow[t]{2}{*}{ hdi } & $-0.004 * * *$ & $-0.056^{* *}$ & $0.025 * * *$ \\
\hline & $(0.001)$ & $(0.027)$ & $(0.002)$ \\
\hline \multirow[t]{2}{*}{$\ln x$} & 0.002 & -0.038 & $0.005^{*}$ \\
\hline & $(0.003)$ & $(0.033)$ & $(0.003)$ \\
\hline \multirow[t]{2}{*}{$\operatorname{lnim}$} & -0.002 & $0.051 * *$ & $-0.003 *$ \\
\hline & $(0.002)$ & $(0.023)$ & $(0.002)$ \\
\hline \multirow[t]{2}{*}{ gex } & $0.002 * *$ & $-0.075^{* * *}$ & 0.001 \\
\hline & $(0.001)$ & $(0.016)$ & $(0.001)$ \\
\hline \multirow[t]{2}{*}{ cpi } & 0.000 & 0.002 & 0.000 \\
\hline & $(0.000)$ & $(0.002)$ & $(0.000)$ \\
\hline \multirow[t]{2}{*}{$\operatorname{lnppc}$} & 0.008 & -0.087 & $0.868 * * *$ \\
\hline & $(0.013)$ & $(0.353)$ & $(0.031)$ \\
\hline \multirow[t]{2}{*}{$\operatorname{lninv}$} & 0.004 & -0.066 & $0.106 * * *$ \\
\hline & $(0.015)$ & $(0.219)$ & $(0.019)$ \\
\hline \multirow[t]{2}{*}{ un } & -0.001 & $0.026^{*}$ & 0.001 \\
\hline & $(0.001)$ & $(0.015)$ & $(0.001)$ \\
\hline \multirow[t]{2}{*}{ di } & 0.000 & 0.003 & 0.000 \\
\hline & $(0.000)$ & $(0.003)$ & $(0.000)$ \\
\hline \multirow[t]{2}{*}{ hp } & $0.028 * * *$ & $-0.281 * *$ & -0.017 \\
\hline & $(0.010)$ & $(0.127)$ & $(0.011)$ \\
\hline \multirow[t]{2}{*}{ Constant } & 0.167 & -7.950 & -0.284 \\
\hline & $(0.354)$ & $(5.691)$ & $(0.494)$ \\
\hline Observations & 330 & 330 & 330 \\
\hline R-squared & 0.25087 & 0.23025 & 0.98794 \\
\hline \multicolumn{4}{|c|}{ Standard errors in parentheses } \\
\hline$* \mathrm{p}<.1, * * \mathrm{p}<.05, * * * \mathrm{p}$ & & & \\
\hline
\end{tabular}

\section{Estimation Result for Sub-sample}

The result in Table 2 showed that the coefficient of FI, FS and the interaction between FI \& FS does not significant on Gini ratio. Since this is panel data analysis using province level data, it also indicates that the effect of FI and FS does not same for all provinces in Indonesia. It might resulted from high variance of deviation from the regression line since each provinces has different behavior. Therefore, the result of the regression might not be significant. It means, there might be different behavior of FI and FS based on the different characteristic of each provinces. Therefore, the next analysis observe the behavior of FI and FS on several different characteristic of provinces, they are HDI, FI and FS. This is conducted by dividing the observation into sub-sample (groups) based on HDI, FI, and FS.

Table 4 demonstrates panel data analysis on provinces with low HDI and 
provinces with high HDI. The categorization of HDI is based on the BPS guidance. Province with the score of HDI greater than 80 is categorized as province with very high HDI. Province with HDI score less than 80 but greater than 70 is categorized as province with high HDI. Province with HDI score less than 70 but greater 60 is categorized as province with moderate HDI. Meanwhile, province with HDI score less than 60 is categorized as province with low HDI.

The analysis in table 6 divide 33 provinces in Indonesia into two categories based on HDI. The first group is provinces with HDI score less than 70. That means, this group consist of provinces with moderate and low HDI. The provinces are Aceh, North Sumatera, Jambi, South Sumatera, Bengkulu, Lampung, Bangka Belitung Island, West Java, Central Java, East Java, West Nusa Tenggara, East Nusa Tenggara, West Kalimantan, South Kalimantan, Central Sulawesi, South Sulawesi, Southeast Sulawesi, Gorontalo, West Sulawesi, Maluku, North Maluku, Papua, and West Papua. All the provinces are categorized as moderate HDI except for Papua with HDI score 57.6 and categorized as low HDI.

The second group consists of provinces with HDI score greater than 70 and categorized as provinces with high HDI. In Indonesia, there are no provinces with HDI score greater than 80 . Therefore, there are no provinces with very high HDI. There are nine provinces in Indonesia that are categorized as provinces with high yearly average HDI. They are West Sumatera, Riau, Riau Island, DKI Jakarta, DI Yogyakarta, Banten, Bali, East Kalimantan, and North Sulawesi. All these provinces scored yearly average HDI a little more than 70, except for DKI Jakarta and DI Yogyakarta which scored 78.9 and 77.7 respectively. These two provinces almost surpass the threshold to be province with very high HDI score.

93 |Juli 20021
Table 4 demonstrated the result of panel data analysis for first group of provinces (provinces with low and moderate HDI) and second group of provinces (provinces with high HDI). The results showed a different behavior of variable of interests when they are observed for Gini ratio as dependent variable. The group of provinces with low and moderate HDI showed that FI, FS and interaction between FI and FS does not significantly affect Gini ratio. It is demonstrated in model 3 with control variables.

Meanwhile, for the group of provinces with high HDI score, FI, FS and the interaction between FI and FS significantly affect Gini ratio. It is demonstrated in model 3 with control variables. The results showed that there are different behavior of FI and FS in provinces with low and moderate HDI and provinces with high HDI. These variables do not significant in explaining Gini ratio in low and moderate HDI provinces, but it significantly affect Gini ratio in high HDI provinces.

In the model, the coefficient of FI is negative. That means, the higher the FI in province with high HDI, the lower the income inequality. The coefficient of FS is also negative. That means, the higher the FS in province with high HDI, the lower the income inequality. Meanwhile, FI and FS does not significantly affect income inequality in provinces with low and moderate HDI.

HDI or human development index consists of three key indicators, they are income, health, and education. Provinces with relatively higher HDI is said to be more developed in terms of their people's income, health, and education, and vice versa. Therefore, the results give a brief idea that financial development in the form of FI and FS has the ability to decrease income inequality with high HDI, while the same 
case does not applied in provinces with low and moderate HDI. It indicates that the transmission mechanism of financial inclusion on decreasing income inequality depends on human capital in the corresponding area. If the human capital is deemed capable of handling and managing their access on financial product and services, then transmission mechanism of financial inclusion to decrease income inequality is highly possible to happen. However, if the human capital is deemed not capable (indicated by low HDI), then their access on financial product and services could not be managed effectively and efficiently to reduce income inequality.

Table 4. Regression Result for sub-sample based on HDI

\begin{tabular}{|c|c|c|c|c|c|c|}
\hline \multirow{3}{*}{ var } & \multicolumn{3}{|c|}{ low and moderate HDI } & \multicolumn{3}{|c|}{ high HDI } \\
\hline & \multicolumn{3}{|c|}{ Gini } & \multicolumn{3}{|c|}{ Gini } \\
\hline & $\mathbf{1}$ & 2 & 3 & $\mathbf{1}$ & 2 & 3 \\
\hline \multirow[t]{2}{*}{ FI1 } & -0.151 & $2.582^{*}$ & 2.129 & -0.242 & 0.880 & $-5.036 * *$ \\
\hline & $(-0.181)$ & $(-1.422)$ & $(-1.367)$ & $(0.000)$ & $(-1.595)$ & $(-2014)$ \\
\hline \multirow[t]{2}{*}{ FS } & -0.031 & $2.459^{*}$ & 1.411 & -0.008 & 1072 & $-4.468 * *$ \\
\hline & $(-0.065)$ & $(-1.287)$ & $(-1.248)$ & $(0.000)$ & $(-1.491)$ & $(-1892)$ \\
\hline \multirow[t]{2}{*}{ filfs } & & $-8.321 *$ & -4.659 & & -3471 & $14.511 * *$ \\
\hline & & $(-4.296)$ & $(-4.195)$ & & $(-4.770)$ & $(-6069)$ \\
\hline \multirow[t]{2}{*}{ lit } & & & 0.000 & & & $-0.007 * * *$ \\
\hline & & & $(-0.002)$ & & & $(-0.003)$ \\
\hline \multirow[t]{2}{*}{ hdi } & & & $-0.006^{* * *}$ & & & 0.001 \\
\hline & & & $(-0.001)$ & & & $(-0.002)$ \\
\hline \multirow[t]{2}{*}{$\ln x$} & & & $0.006^{* *}$ & & & $-0.020 *$ \\
\hline & & & $(-0.003)$ & & & $(-0.011)$ \\
\hline \multirow[t]{2}{*}{$\operatorname{lnim}$} & & & -0.003 & & & $0.010^{* *}$ \\
\hline & & & $(-0.002)$ & & & $(-0.004)$ \\
\hline \multirow[t]{2}{*}{ gex } & & & $0.001 *$ & & & $0.003 * *$ \\
\hline & & & $(-0.001)$ & & & $(-0.002)$ \\
\hline \multirow[t]{2}{*}{ cpi } & & & 0.000 & & & 0.000 \\
\hline & & & $(0.000)$ & & & $(0.000)$ \\
\hline \multirow[t]{2}{*}{$\operatorname{lnppc}$} & & & -0.002 & & & -0.006 \\
\hline & & & $(-0.015)$ & & & $(-0.017)$ \\
\hline \multirow[t]{2}{*}{$\operatorname{lninv}$} & & & $0.016^{* *}$ & & & $0.023 * * *$ \\
\hline & & & $(-0.006)$ & & & $(-0.008)$ \\
\hline \multirow[t]{2}{*}{ un } & & & $-0.004 * *$ & & & $0.004 * * *$ \\
\hline & & & $(-0.002)$ & & & $(-0.002)$ \\
\hline \multirow[t]{2}{*}{ di } & & & 0.000 & & & $0.001 * *$ \\
\hline & & & $(0.000)$ & & & $(-0.001)$ \\
\hline \multirow[t]{2}{*}{ hp } & & & 0.008 & & & $0.058 *$ \\
\hline & & & $(-0.011)$ & & & $(-0.03)$ \\
\hline \multirow[t]{2}{*}{ Constant } & $0.418 * * *$ & -0.401 & -0.064 & $0.453 * * *$ & 0.105 & $2.295 * * *$ \\
\hline & -0.06 & -0.427 & -0.453 & 0 & 0 & -0.672 \\
\hline Observations & 264 & 264 & 240 & 99 & 99 & 90 \\
\hline \multicolumn{7}{|c|}{$* \mathrm{p}<.1, * * \mathrm{p}<.05, * * * \mathrm{p}<.01$} \\
\hline
\end{tabular}


Meanwhile in the model 3 of provinces with high HDI, interaction variable between FI and FS has positive coefficient. That means, the interaction between these variables in the form of linkage program strengthen the effect of FI on Gini ratio and the effect of FS on Gini ratio. It indicates that under a proper management of capable human capital, the interaction between FI and FS such as linkage program could strengthen the effect of financial inclusion on reducing income inequality.

This study also analysed the effect of FI and FS on income inequality by dividing the provinces into two groups based on yearly average score of financial inclusion index. the categorization of financial inclusion index is based on Sarma (2015). Provinces with FI score that is greater than 0.5 is categorized as provinces with high FI. However, there are no provinces in Indonesia that scored more than 0.5 on its FI. Provinces with FI score between 0.3 and 0.5 are categorized as provinces with moderate FI.

Meanwhile, provinces with FI score lower than 0.3 are categorized on provinces with low FI. For the case of Indonesia, the first group consists of provinces with moderate FI, they are North Sumatera, Bengkulu, Bangka Belitung, Riau Island, DKI Jakarta, DI Yogyakarta, Bali, East Nusa Tenggara, West Kalimantan, South Kalimantan, North Sulawesi, South Sulawesi, Gorontalo, Maluku, North Maluku, and West Papua. Meanwhile, the second group consists of provinces with low FI, they are Aceh, West Sumatera, Riau, Jambi, South Sumatera, Lampung, West Java, Central Java, East Java, Banten, West Nusa Tenggara, Central Kalimantan, East Kalimantan, Central Sulawesi, Southeast Sulawesi, West Sulawesi and Papua. The result showed that there are no different behavior demonstrated by both groups. Variables of interest in this study does not demonstrate significant coefficient.

\section{Discussions}

Based on the result demonstrated in table 3 and table 4, there are several ideas that can be concluded. First, financial inclusion and financial structure does not demonstrate significant coefficient for income inequality and poverty. This result is consistent with the finding of Ummah (2015) and Aginta et al (2019). For the case of Indonesia, specifically provincial data, the relationship between financial inclusion and income inequality is hardly spotted. Studies that analyse this topic often found significant effect of financial inclusion and income inequality using aggregate data in national level, for example, the study of Hanivan \& Nasrudin (2019). However, when it breaks down into provincial data, the relationship is no longer clearly spotted. Ummah (2015) and Aginta et al (2018) used provincial data and found similar results.

There are several possibilities that leads to this kind of result. First, the problem of measurement coverage. There are only three indicators that formed the financial inclusion index, they are the number of offices, third party fund and credit. There are possibilities that those indicators are not enough to cover all aspects of financial inclusion. Meanwhile, the indicator of financial structure is formed only from microbanking aspect, specifically rural bank (BPR). In fact, there are several other microfinance institution other than BPR and probably has different characteristic than BPR. For example, Baitul Maal wat Tamwil (BMT) that is common to be found in Indonesia. Compared to BPR, BMT is considered to be more accessible for even 
poorer group. BMT staffs actively go around to find its customer instead of waiting for them in the office. Moreover, BMT operates based on religious value. In Indonesia, religious value tends to lead into higher trust for its people, as Indonesia is muslim majority country.

Aside from the technical obstacles explained in the previous paragraph, this insignificant result also indicates that the behaviour of variables of interest on Gini ratio might be different for each province. Therefore, this study analysed the effect of FI and FS on Gini ratio by dividing the observations into groups. Table 4.4 demonstrate the division of groups based on HDI. The result showed that provinces with moderate and low HDI demonstrated insignificant effect of FI and FS on income inequality. However, for provinces with high HDI, FI and FS demonstrate significant and negative effect on income inequality. That means, the behaviour of FI and FS on affecting income inequality depends on human capital in each province. Provinces with high HDI is deemed to have proper quality of human capital. Therefore, they have higher ability on handling and managing access on financial product and services to reduce income inequality between this group. Meanwhile, provinces with moderate and low HDI has limited ability to handle and manage financial development to reduce income inequality.

In the other hand, the insignificant effect could also indicate that financial inclusion program implemented in Indonesia has not meet its goal to reduce income inequality. The mechanism could go wrong in any points, however, the fact that most formal financial institution in Indonesia still operates similarly with general banking might be one of the major reasons. BPR is considered more accessible for poorer group of people since it relatively has smaller size and less complex requirement both for saving or financing (credit). However, saving side of the institution is accessible for all segments of people while the financing (credit) side is still limited to certain segment of people that meets the requirement to borrow their fund. That means, the segment of poor people that benefitted from rural bank's financing product are those that has considerably low risk. Meanwhile, people that is not meet the requirement of this segment can only save but cannot borrow the fund of this financial institution.

Moreover, due to its naturally higher risk, rural bank has higher interest rate compared to general bank. Therefore, even when the certain segment of people is bankable according to BPR, they still get the fund that is rather costly. Meanwhile, nonpoor people are eligible for relatively cheaper fund in general bank. These scenarios might be the reasons of why financial inclusion and financial structure in the means of microbanking aspect do not have significant effect on income inequality. Moreover, there are also indication of worst case that is the positive relationship between financial inclusion and income inequality as graphical analysis demonstrated so.

\section{Conclusion and Policy Implication}

There are three objectives of this study. First is to estimate the effect of financial inclusion on income inequality and second is to estimate the effect of financial structure on income inequality. Based on the graphical analysis, financial inclusion and income inequality has positively sloped trend line. That means the higher the financial inclusion, the higher income inequality would be. Accordingly, this 
relationship is not confirmed as financial inclusion does not significantly affect income inequality, instead, it has significant and positive effect on GRDP. Based on the graphical analysis, financial structure does not appear to have a significant relationship with income inequality. This result was in line with Ummah et al (2015) and Aginta et al (2018). These studies observe the case of Indonesia. However, the result was not in line with the other existing studies which observe global case or other country case.

However, the insignificant coefficient might also indicate that the behavior of financial inclusion and financial structure might be different based on the characteristic of each province. Therefore, this study also analyzed the effect of financial inclusion and financial structure on income inequality by dividing the observations into groups. Group division based on HDI score demonstrates different behavior of variables of interest. For group of provinces with moderate and low HDI, FI and FS does not demonstrate significant coefficient. Meanwhile, for group of provinces with high HDI, FI and FS demonstrate significant and negative effect on Gini ratio. That means, behavior of financial development on affecting income inequality depends on human capital in each province. This result was in line with Park \& Mercado (2015) which found a positive relationship between financial inclusion and human resource quality.

Based on the result of the study, the result of panel regression using all observations, financial inclusion does not significantly affect income inequality, and neither does the interaction with financial structure. Meanwhile, for provinces with high HDI, financial inclusion significantly affects income inequality in negative sign. While the interaction between financial inclusion and income inequality strengthens the effect of financial inclusion on income inequality. Therefore, it is important to consider human resource quality.

The mean score of HDI for all provinces in Indonesia since 2010 to 2020 is 68.5. It is included in the 'moderate' category, but it is quite close the threshold of 70 for high HDI. The national strategy of financial inclusion as stated in the President Decree 2020 could reach its goal in reducing income inequality by considering two things. First, the preparation of human resource involved in this national strategy and second, consider the development of microfinance institution as it is proved to strengthen the effect of financial inclusion on income inequality.

To further develop future studies, there are several points that could be conducted. First, the future studies are suggested to include financial sector other than banking. Second, to measure financial structure, future studies are suggested to include microfinance sector other than BPR (rural bank), it is also highly suggested to include Baitul Maal wat Tamwil (BMT) as it is indicated to have different characteristic than BPR and is expected to have more important role in the implementation of financial inclusion programs.

\section{REFERENCES}

Aginta, H., Soraya, D. A., \& Santoso, W. B. (2018). Financial Development and Income Inequality in Indonesia: A Sub-National Level Analysis. Economics and Finance in Indonesia, 64(2), 111-130.

Akbar, M. (2018). Regional Openness and Regional Inequality. Master Theses Department of Economics University of Indonesia, 1-87.

Allen, M. (2017). Variables, Moderating Types. Sage Publishing. 
Bangoura, L., Momar Khary Mbow, A. L., \& Diaw, D. (2016). Impact of Microfinance on Poverty and Inequality: A Heterogeneous Panel Causality Analysis. Review of Economics and Politics, 126, 789-818.

Beck, T. (2006). Creating an Efficient Financial System: Challenges in a Global Economy. World Bank Policy Research Working Paper, 1-43.

Camara, N., \& Tuesta, D. (2014). Measuring Financial Inclusion Index. Working Paper BBVA Research, 1-41.

Chrisyanto, C. (2006). Faktor-faktor yang Mempengaruhi Ketimpangan Perekonomian Antar Daerah di Indonesia. Tesis Magister Perencanaan dan Kebijakan Publik Fakultas Ekonomi Universitas Indonesia, 1-106.

Desfiandi, A. (2014). Social Security Spending and Income Inequality in Indonesia. Master Thesis Department of Economics University of Indonesia, $1-39$.

Deyshappriya, N. P. (2017). Impact of Macroeconomic factors on income inequality and income distribution in Asian countries. Asian Development Bank Working Paper, 1-21.

Dhrifi, A. (2013). Financial Development and Poverty: What Role for Growth and Inequality? International Journal of Academic Research in Accounting, Finance and Management Science, 119-129.

Erlando, A., Riyanto, F. D., \& Masakazu, S. (2020). Financial Inclusion, economic growth, and poverty alleviation: evidence from eastern Indonesia. Heliyon, 6(10).
Fouejieu, A., Sahay, R., Cihak, M., \& Chen, S. (2020). Financial Inclusion and inequality: A cross country analysis. The Journal of International Trade \& Economic Development.

Ghosh, J. (2013). Microfinance and the challenge of financial inclusion for development. Cambridge Journal of Economics, 1203-1219.

Hanivan, H., \& Nasrudin, N. (2019). A Financial Inclusion Index for Indonesia. Bulletin of Monetary Economics and Banking, 22(3), 351366.

Honohan, P. (2008). Cross-country variation in household access to financial services. Journal of Banking and Finance, 2493-2500.

Jauch, S., \& Watzka, S. (2016). Financial Development and Income Inequality: A Panel Data Approach. Empirical Economics, 291-314.

Kendall, J., Mylenko, N., \& Ponce, A. (2010). Measuring Financial Access around the World. Policy Research Working Paper, 1-67.

Kuznets, S. (1955). Economic growth and income inequality. The American Economic Review, 1-28.

Le, Q. H., Ho, H. L., \& Mai, N. C. (2019). The impact of financial inclusion on income inequality in transition economies. Management Science Letters, 661-672.

Leuween, B. v., \& Foldvari, P. (2016). The Development of Inequality and Poverty in Indonesia. Bulletin of Indonesian Economic Studies, 52(3), 379-402.

Liu, G., \& Zhang, C. (2018). Does Financial Structure Matter for Economic Growth 
in China. China Economic Review. doi:10.1016/j.chieco.2018.06.006

Malerba, G., \& Spreafico, M. (2014). Structural Determinants of Income Inequality in the European Union: Evidence from a Panel Analysis. Rivista Internazionale Di Scienze Sociali, 122(1), 37-83.

Mushtaq, R., \& Bruneau, C. (2019). Microfinance, Financial Inclusion and ICT: Implications for Poverty and Inequality. Technology in Society(59), 101-154. doi:10.1016/j.techsoc.2019.101154

OECD. (2007). The Financial Sector's Contribution to Pro-Poor Growth . In OECD, Promoting Pro-Poor Growth. Paris: OECD Publishing.

Park, C.-Y., \& Mercado, R. V. (2015, January). Financial Inclusion, Poverty, and Income Inequality in Developing Asia. ADB Economics Working Paper Series.

Piketty, T. (2014). Capital in the TwentyFirst Century. Harvard University Press.

Prasetyo, B. A., Priyarsono, D. S., \& Mulatsih, S. (2013). Infrastructure, Economic growth and Inequality in Indonesia Land Borders. Economic Journal of Emerging Markets, 5(2), 99-108.

Ray, D. (1998). Development Economics. West Sussex: Princeton University Press.

Refqi, M., \& Hidayat, A. K. (2019). Determinants of Regional Disparities in Indonesia: Lesson from Provincial Level. Working Paper in Economics and Development Studies Padjadjaran University, 1-24.
Sarma, M. (2008). Index of Financial Inclusion. ICRIER Working Papers No. 125.

Sarma, M. (2015). Measuring Financial Inclusion. Economics Bulletin, 35(1), 604-611.

Sarma, M., \& Pais, J. (2011). Financial Inclusion and Development. Journal of International Development, 23(5).

Sen, A. (2009). The Idea of Justice. Massachusetts: The Belknap Press of Harvard University Press.

Silva, I. D., \& Sumarto, S. (2014). Does Economic Growth Really Benefit the Poor? Income Distribution Dynamics and Pro-Poor Growth in Indonesia. Bulletin of Indonesian Economic Studies, 50(2), 227-42.

SNKI. (2018). Financial Inclusion Insights Indonesia 2018. Jakarta: Kemenko Perekonomian RI.

Soetiono, K. S., \& Setiawan, C. (2018). Literasi dan Inklusi Keuangan Indonesia. Depok: Rajawali Press.

Suryahadi, A., Suryadarma, D., \& Sumarto, S. (2006). Economic growth and poverty reduction in Indonesia: The effect of location and sectoral components of growth. SMERU Working Paper, 1-33.

Tang, X., \& Yao, X. (2018). Do Financial Structures Affect Exchange Rate and Stock Price Interaction? Evidence from Emerging Markets. Emerging Markets Review, 43, 64-76. doi:10.1016/j.ememar.2017.10.004

Todaro, M. P., \& Smith, S. C. (2012). Economic Development 11th Edition. Boston: Person.

Tridico, P. (2017). The determinants of income inequality in OECD countries. 
Cambridge Journal of Economics, 134. doi:10.1093/cje/bex069

Ummah, B. B., Nuryartono, N., \& Anggraeni, L. (2015). Analisis Inklusi Keuangan dan Pemerataan Pendapatan di Indonesia. Jurnal Ekonomi dan Kebijakan Pembangunan, 4(1), 1-27.

Wang, X., \& Guan, J. (2017). Financial inclusion: measurement, spatial effects and influencing factors . Applied Economics, 1751-1762.

World Bank. (2019, November 2). Financial Inclusion. Retrieved from The World Bank Official Website: https://www.worldbank.org/en/topic/fi nancialinclusion/overview\#1 